GLOBAL MEDICAL ETHICS

\title{
The physician and prison hunger strikes: reflecting on the experience in Turkey
}

\author{
N Y Oguz, S H Miles
}

J Med Ethics 2005;31:169-172. doi: 10.1136/jme.2004.006973

The medical ethics of a physician's relationship with a prisoner who is participating in a collective hunger strike has become a major public, professional, and governmental concern in The Republic of Turkey. This article examines the Turkish experience and debate about physician ethics during prison hunger strikes. It is hoped that this analysis will be of use to those formulating policy in similar situations.

See end of article for authors' affiliations .....................

Correspondence to: Professor N Y Oguz, Ankara University School of Medicine, Department of Medical Ethics, Morfoloji Yerleskesi Sihhiye, Ankara 06100, Turkey; oguzx001@ yahoo.com

Received 24 October 2003 In revised form 29 January 2004 Accepted for publication 14 February 2004 strike in the sense that it harms health or causes death.

Most hunger strikes include the ingestion of some water or other liquids, salt, sugar, and vitamin $\mathrm{Bl}$ for a certain time without asserting intent to fast to death. During the last hunger strike in Turkey, a new term, "death fast," arose. A person on a death fast takes water, salt, sugar, and vitamin $\mathrm{Bl}$ and asserts that the fasting will continue to death unless the aims of the strike are met. ${ }^{14}$ The ingested vitamins decrease the chance of permanent nutritional disability (neuropathy or congestive heart failure) if the strike should end. Although death fasts cause a progressive and eventually lethal protein and caloric malnutrition, the fluids and ingested nutrients extend the duration of negotiation with regard to the aims of the strike. Most hunger strikers are trying to effect political change rather than trying to become martyrs, commit suicide, or maim themselves with nutritional deficiencies. A death fast increases the pressure on the negotiation.

\section{THE EXPERIENCE IN TURKEY}

The medical ethics of hunger strikes have been intensely debated in Turkey during the collective prison hunger strikes of 1996 which recommenced in 2000 and have lasted to the present time. The prisoners' aims of the 1996 strike were for relief from being beaten, placed in isolation cells, denied medical care, or being moved to prisons far from their families and lawyers. ${ }^{15}$ During that strike, the Ministry of Health maintained that government employed physicians who worked with prisoners in government hospitals were obliged to save human life, including assisting in force feeding and providing medical treatment to unconscious hunger strikers. In response, the Turkish Medical Association (TMA) asserted that feeding and treating the hunger strikers against their will violated the principle of informed consent with regard to the right to refuse medical treatment. This view of the relevance of informed consent as it pertains to hunger striking was articulated by the World Medical Association (WMA). ${ }^{1}$ This placed physicians in a difficult position. Most physicians are government employees and 80\% belong to the TMA. Physicians also had serious difficulty in assuring prisoner patient confidentiality. Twelve prisoners died and many more suffered permanent neurological damage during the 1996 strike. ${ }^{16}{ }^{17}$ This experience led to intense discussions about the need for an ethics statement to guide medical practice during hunger 
strikes; however, many meetings failed to reconcile the various views on the duties of physicians.

In August 2000, the government began to implement a long debated plan to place prisoners in F-type prisons in which cells holding one to three persons replaced large communal cellblocks. The government promoted the new prisons as conforming to European Union standards calling for prisoners to be placed in cells rather than open wards. ${ }^{16}{ }^{18}$ Though most parties agreed that crowded wards posed public health risks, the government also saw the new prisons as a way to regain control over prisoners' organisations in communal cell blocks. ${ }^{15}$ Prisoners, their relatives, human rights advocates, and the TMA opposed the shift to small cells maintaining that social control was the primary reason for the new government policy. They also cited the adverse social and psychological consequences of isolating the prisoners and the prisoners' greater vulnerability to torture. ${ }^{19-21}$

On 20 October 2000, four illegal political organisations initiated prison hunger strikes across Turkey. ${ }^{17}$ Strikers organised into cohorts that began refusing food at different times to spread out the duration of the strike. As during the 1996 strikes, trusted physicians gave prisoners medical advice on how to take vitamins to prevent permanent neurological defects after the strike. The government cited the coordinated nature of the strikes, including the use of cell phones from inside prisons, as evidence for uncontrolled communication between prisoners and as confirming the need to re-establish control over inmates. By November, the government showed no sign of accepting the strikers' goals. The hunger strikers made the fast more rigorous and announced that participants would die, rather than fast, to advance their collective goals. ${ }^{22}$ Citing the need for swift action to prevent deaths, security forces moved against the prisoners in December. During the ensuing violence, 30 prisoners and two security personnel reportedly died. The government reported that about half of the prisoners who died set themselves on fire ${ }^{16}$ but some nongovernmental sources stated that the burns and deaths were caused by chemical gases that were used as weapons against the prisoners. ${ }^{22}$ Some of the remaining hunger strikers were hospitalised. On 16 April 2001, the Counselor of the Ministry of Health said that 222 prisoners were on a death fast, 569 were on hunger strikes, and 153 prisoners were hospitalised. ${ }^{23}$

In the hospitals, the ethical problem for physicians was again joined. The government pressed physicians to force feed and treat the strikers against their will. The TMA again stated that it was unethical to do so. Domestic and international political pressures focused on the government's duty to establish control over prisoners and to remedy human rights abuses in Turkish prisons. While the debate within the medical community and between physicians and government representatives continued, the chairperson of the TMA stated that the Honorary Board of the Association might investigate physicians who fed or treated strikers without consent. ${ }^{24}$ This marked a change from the earlier TMA advisory opinion urging physicians to respect the consent of a person on a hunger strike and it went further than the WMA, which left the ultimate decision as to how to proceed to the individual physician. ${ }^{1}$ The government declared that physicians who refused to force feed would be subject to judicial investigations. ${ }^{25} 26$ Some journalists accused the TMA of taking a political position outside of its mission to save lives and promote health. The Attorney General took the TMA to court for going beyond its government charter in criticising prison conditions and the government's intervention, but withdrew the complaint and a judge ruled that the accusation was not valid. ${ }^{27}$

The hunger strikes and death fasts continued throughout 2003, taking more than a hundred lives. ${ }^{28}$ In addition to strikes in prisons and hospitals, former prisoners, their friends, and the relatives of prisoners went on hunger strikes in private homes. In November 2001, governmental forces attacked houses where people were on hunger strikes. Several people died during the attack, although it is not clear whether these deaths were a result of suicide or government force. ${ }^{22} 29$ The government again declared that the strikers would be force fed and proposed amending the Turkish Penal Code to allow a sentence of 20 years in prison for those who encourage hunger strikes. ${ }^{30}$

\section{DISCUSSION}

Much of medical ethics in life and death decisions is grounded on reconciling respect for the sanctity of life with respect for individual decisions. The decision to refuse nutrition is one of the few ways in which a person without access to weapons or poisons can make a life or death decision. In ordinary clinical settings, it is widely agreed that a person may choose to refuse life sustaining food. The prison hunger strike raises the issue of whether the ethics that pertain to free citizens also pertain to the physician's relationship with a prisoner patient. Prison authorities have a legitimate interest in preventing suicide and in maintaining social control over health and security in the prison environment. However, in either clinical or political settings, the choice to refuse food can be an authentic, albeit lethal, expression of values that may end the chooser's life. Studies showed that prisoners who go on hunger strikes have a high prevalence of depression or post-traumatic stress disorder but are not especially likely to be suicidal or incapable of making a decision to go on a hunger strike. ${ }^{31-33}$

People who challenge state authorities with a hunger strike intend to summon the attention of a broad public audience to the issue that engenders the strike and the aim of the strikers in addressing that issue. Public attention on a hunger strike broadens the dilemma for the state authority whose policies are challenged by the strike. ${ }^{10}$ Allowing the striker to die ratifies the charge that the authority does not value the personhood of prisoners. Forced feeding to "save life" draws attention to the way the diminished quality of life has inspired the protest. Any response by the state including neglect, negotiation, or forced feeding is a form of dialogue with the strikers and with the broader audience of the strike.

\section{THE RELATIONSHIP OF PHYSICIAN AND HUNGER STRIKER}

Several medical organisations have proposed principles for the conduct of the physician-hunger striker relationship. ${ }^{15}{ }^{34-36}$ Such documents generally advocate respect for an informed and freely chosen decision to strike. Their disposition is mainly based on the concept of freedom of expression introduced by the International Covenant on Civil and Political Rights. ${ }^{37}$ The Covenant supports all means of expression unless they cause a threat to third parties or the public. For prisoners, conventional means of political expression such as voting, donating to political organisations, publishing, or national organising are greatly diminished. They are obstructed, impracticable, or illegal. Under these circumstances, a hunger strike asserting bodily integrity is one of the few tools for strong political expression. By sparing the threats to the self as permissible, the Covenant protects an effective way of expression and communication.

Aside from the imprisoned status of the hunger striking patient, the political aim of hunger striking profoundly reshapes the relationship between the physician and the patient who is refusing food. ${ }^{38} \mathrm{~A}$ physician who either 
respects the choice to hunger strike or force feeds a striker is engaged in a political act. ${ }^{6} 133839$ To minimise the political agency of the physician, all parties must be able to view the physician as politically neutral with regard to the aims, methods, wisdom, and legitimacy of the strike as that physician counsels or treats a person who is making or has made a choice to go on a hunger strike. In this framework of neutrality, the physician has four responsibilities with regard to working with a hunger striker.

- Firstly, the physician must assess the person's ability to make an informed decision to go on a hunger strike. The assessment of decision making capacity before a strike is underway is like assessing capacity for any other serious decision. A physician will assess for depression and ask for psychiatric assistance as needed. ${ }^{31}{ }^{32}$ Once a strike is underway, depression, delirium, neuropathy, and stupor will eventually impair decision making capacity. ${ }^{35}$ For this reason advance planning is important. The physician should carefully interview the person before and during a strike to assess the decision to strike, and to understand the future social or medical conditions under which the person would consent to refeeding or other medical treatments such as resuscitation. ${ }^{5336} 39$ If decision making capacity is lost, the physician should refrain from or initiate refeeding according to the framework of such advance planning. In the case of a person who is already cognitively impaired, a surrogate decision maker may never properly decide to initiate a hunger strike. However, a person with decision making capacity may designate a surrogate decision maker for the time in a hunger strike when he or she loses competence. The designated surrogate decision maker should not be incarcerated or he/she should not be an official of an organisation that is coordinating a collective hunger strike.

- Secondly, the physician must assess the person's freedom to decide to go on a hunger strike. In the Turkish collective hunger strikes, there was a legitimate concern about the degree to which individual striker's decisions may have been coerced by prisoners' organisations. ${ }^{16}{ }^{16}$ This uncertainty affected the debate about the government's position favouring forced feeding and the TMA's position favouring the acceptance of a prisoner's decision. The government's universal endorsement of feeding certainly disregarded a prisoner's right to go on a hunger strike. The TMA position risked overriding a physician's judgment that a striker's decision was coerced by the prisoners' collective or by a hunger striker being unwilling to stand against peer pressure. ${ }^{17}{ }^{31}$ To ascertain the voluntariness and authenticity of a striker's decision, the physician must interview a potential or actual striker in a private, unmonitored setting. ${ }^{1}$ If a physician learns that a decision to strike is coerced, the physician should ask the prisoner how to work with prison officials to alleviate the pressure on that prisoner. Though separating a prisoner for such interviews may increase vulnerability to state coercion, the individual protests of many people speak more eloquently than a collective strike in which the free choices of participants are questionable.

- Thirdly, the physician should ensure that a potential striker has an informed understanding of the medical implications of a hunger strike. The physician should inform the striker of potential reversible and irreversible harms that may occur during prolonged fasting and how to reduce the risk or severity of irreversible disabilities if a strike is discontinued. There are few data to guide such patients. ${ }^{40}$ Most authorities agree that B vitamins, especially thiamine to prevent Wernicke's encephalopathy, are important to lessen the risk of irreversible brain damage. ${ }^{41}$
Conventional clinical and laboratory findings of serious metabolic derangements may not be seen in slender, healthy people on a hunger strike. ${ }^{33} 4042$ For example, skin turgor may not reliably indicate dehydration and ingesting sugar may precipitate Wernicke's encephalopathy.

- Fourthly, the physician must be willing to supervise hospitalisation or refeeding if a striker chooses to accept medical care, feeding, or if the striker's conditions for ending a fast are met subsequent to the loss of decision making capacity. ${ }^{33} 43$ The physician and hospital administration must work create proper clinical relationships within the security environment. ${ }^{44}$

This outline of the physician's responsibilities suggests the contours of a government policy with regard to physicians and imprisoned hunger strikers. Governments should allow prisoners to exercise the political expression of a hunger strike. ${ }^{37}$ Governments should allow physicians to be neutral with regard to a hunger strike and should not compel physicians to engage in force feeding which damages prisoner-physician relationships that are essential for other aspects of health programmes in prisons. ${ }^{5}$ Governments should allow physicians to meet potential or active hunger strikers in unmonitored rooms so that the physician can assess the prisoner's choice to strike ${ }^{40}{ }^{45}$ The government and physicians' professional organisations should accommodate and work with physicians who have made a clinical conclusion that a decision to go on a hunger strike is coerced.

Physicians who treat potential hunger strikers should be willing to be professionally neutral with regard to the political aims of the strike while respecting the general right to refuse food, nutrients, and fluids. This means that they should, as much as is possible, conscientiously and fairly assess the decision making capacity and freedom from coercion of a potential striker or a prisoner who is engaged in a strike. ${ }^{1}$ They should be willing to proactively provide information on advance planning for the loss of decision making capacity and to enable a person to delay death and decrease the chance of irreversible disabilities. A physician should refrain from advocacy or criticism of the political aspirations of named people under his or her personal care. A physician who is unwilling to perform these roles may refuse to engage in a relationship with hunger strikers.

Hunger strikes pose a moral problem for organised medicine. In the Turkish experience, the government's and the TMA's principles, and international guidelines provided inadequate guidance to physicians. The government's position forced physicians to take one side of the political issue that was at the heart of the hunger strike. The TMA's principles left no room for the attending physician to make his own professional decisions about the authenticity of a prisoner's decision. Both sides politicised bedside clinical judgment. International guidelines also failed to take into consideration the ethical issues posed by collectively organised prison hunger strikes. The role of ethics committees in the conflicts generated by the medical management of hunger strikes deserves to be explored. ${ }^{56}$

Hunger strikes take various forms: some involve free citizens, some involve prisoners, some are individual protests, and some are collective endeavours. Some have legitimate aims but others aim for the impossible. These differences matter and an ethical analysis must rest on a clear, delimited definition of the kind of strike that is being considered.

\section{ACKNOWLEDGEMENT}

The authors wish to thank Murat Civaner, MD for his contributions in documenting the events during the strikes (1996 and 2000) in Turkey. 


\section{Authors' affiliations}

N Y Oguz, Ankara University School of Medicine, Ankara, Turkey S H Miles, Center for Bioethics, University of Minnesota, Minneapolis, MN USA

Competing interests: none declared

\section{REFERENCES}

1 World Medical Association. Declaration on hunger-strikers (1991), Adopted by the 43rd World Medical Assembly Malta, November 1991 and editorially revised at the 44th World Medical Assembly Marbella, Spain, September 1992. http://www.wma.net/e/policy/h31.htm (accessed 20 August 2004).

2 Tagawa BK. Prisoner hunger strikes: constitutional protection for a fundamental right. Am Crim Law Rev 1983;20:569-98.

3 Peel M. Hunger strikes. BMJ 1997;315:829-30.

4 Ludwig GA. Hunger striking: freedom of choice or the state's best interest? N Engl J Crim Civ Confin 1983;10:169-92.

5 Silove D, Curtis J, Mason C, et al. Ethical considerations in the management of asylum seekers on hunger strike. JAMA 1996;276:410-15.

6 Reyes H. Medical and ethical aspects of hunger strikes in custody and the issue of torture. Extracted from maltreatment and torture. In, Oehmichen $M$, ed. Research in Legal Medicine, [vol 19], Lubeck:Verlag Schidt-Romhild, 1998. Published on the website of the International Committee of the Red Cross, www.icrc.org/eng (accessed 20 August 2004).

7 Greenberg JK. Hunger striking: the constitutionality of force-feeding. Fordham Law Rev 1983:51:747-70.

8 Strauss SA. Legal questions surrounding hunger strikes by detainees and prisoners. Med Law 1991;10:211-18.

9 Sunshine SC. Should a hunger-striking prisoner be allowed to die? Boston Coll Law Rev 1984;25:423-58.

10 Annas GJ. Prison hunger strikes: why the motive matters? Hastings Cent Rep $1982 ; 12: 21-2$

11 Potas I. Schneidas v Corrective Services Commission and ORS. Crim Law J 1983;7:353-4

12 Neoral L. Ethical and medico-legal problems concerning so-called hunger strikers. Forensic Sci Int 1994;69:327-8.

13 Ansbacher R. Force feeding hunger strikers: a framework for analysis. Univ Fla Law Rev 1983;35:99-129.

14 Ankara Tabip Odasi (The physician's chamber of Ankara). Aclik Grevleri Atolye Calismasi Sonuc Bildirgesi (Final declaration of hunger strikes workshop). Hekimden Hekime (From physician to physician) 2001. In Turkish, www.ato.org.tr/dergi/2001_ilkbahar/14.html (accessed 20 August 2004).

15 Beynon J. Hunger strike in Turkish prisons. Lancet 1996;348:737.

16 Embassy of the Republic of Turkey (Belgium). Information note on hunger strikers and death fasts in Turkish prisons and operation "return to life." www.turkey.be/En/pkk/noteing.htm (accessed 20 August 2004).

17 Anderson S. The hunger warriors. NY Times Mag 21 Oct 2001:42-7, 74 124-5.

18 Committee of Ministers of the Council of Europe. European prison rules. Recommendation no: RC 87/3, Strasbourg.02/12/, 1987.

19 Kandela P. Careful smiles around the Blue Mosque in Turkey. Lancet 1998;352:1043.

20 Turkish Medical Association. Special report on the medical issues about the F-type prisons. In Turkish, www.ttb.org.tr/rapor/f_tipi.html (accessed 20 August 2004).

21 Salinsky M. Torture continues in Turkey: findings of new report. Lancet 1998;352:1854.
22 The Human Rights Foundation of Turkey Documentation Center. Turkey: file on prisons. Special Report, January 2001, www.tihv.org.tr (accessed 20 August 2004).

23 Anon. Mustesarlar, olum orucu icin toplandi (The Counsellors met to discuss the death fasts) [News]. Hurriyet 16 April 2001 (in Turkish).

24 Anon. Sayek: eylem hemen bitmezse olum olur (Sayek: if the action is not stopped immediately, there will be some deaths) [News]. Hurriyet 5 December 2000 (in Turkish).

25 Anon. Mudahale etmeyen hekime sorusturma acilacak (Physicians who do not intervene will be investigated) [News]. Hurriyet 22 December 2000 (in Turkish).

26 World Medical Association. WMA warned about mounting campaign against Turkish doctors, 2 January 2001 http://www.wma.net/e/press/ 01 01.html (accessed 10 March 2002)

27 Turkish Medical Association. Press release, 11 June 2001. In Turkish, www.ttb.org.tr (accessed 17 April 2002).

28 Anon. Ölüm orucunda 107. kayıp (107th loss in death fast) [News]. Radikal 26 March 2003 (in Turkish).

29 Anon. Kucukarmutlu'ya operasyon (Operation to Kucukarmutlu) [News]. Hurriyet 5 November 2001 (in Turkish)

30 Anon. Olum orucunu "tesvik edene" 20 yil hapis 20 years imprisonment for the ones who encourage death fast) [News]. Hurriyet 8 November 2001 (in Turkish).

31 Brockman B. Food refusal in prisoners: a communication or a method of selfkilling? The role of psychiatrist and resulting ethical challenges. J Med Ethics 1999;25:451-6.

32 Larkin EP. Food refusal in prison. Med Sci Law 1991;31:41-4.

33 Kalk WJ, Felix M, Snoey ER, et al. Voluntary total fasting in political prisoners-clinical and biochemical observations. S Afr Med J 1993;83:391-4.

34 British Medical Association. Medicine betrayed: participation of doctors in human rights abuses. London: Zed Books, 1992:12

35 WHO Regional Office for Europe. Declaration on the promotion of patients' rights in Europe. Amsterdam: WHO, 1994, http://www.inserm.fr/ethique/ Ethique.nsf/ (accessed 20 August 2004).

36 Johannes Wier Foundation for Health and Human Rights. Assistance in hunger strikes: a manual for physicians and other health personnel in dealing with hunger strikers. Amersfoort, Netherlands: JWFHHR, 1995.

37 United Nations. International Covenant on Civil and Political Rights, GA res 2200A (XXI), 21 UN GAOR Supp.(No.16) at 52, UN Doc A/6316 (1966), 999 UNTS 171, entered into force 23 March, 1976.

38 Lewey L. Force-feeding-a clinical or administrative decision? CMAJ 1977;116:416, 419.

39 Frommel D, Gauthier M, Questiaux E, et al. Voluntary total fasting: a challenge for the medical community. Lancet 1984;1:1451-2.

40 Keeton GR. Hunger strikers - ethical and management problems. S Afr Med J 1993;83:380-1.

41 Oge AE, Boyaciyan A, Gokmen E, et al. Neuromuscular consequences of prolonged hunger strike: an electrophysiological study. Clin Neurophysio 2000; 111:2064-70.

42 Scobie IN. Weight loss will be much faster in lean than in obese hunger strikers. BMJ 1998:316:707.

43 Faintuch J, Soriano FG, Ladeira JP, et al. Refeeding procedures after 43 days of total fasting. Nutrition $2001 ; 17: 100-4$

44 Kalk W, Veriawa Y. Hospital management of voluntary total fasting among political prisoners. Lancet 1991;337:660-2.

45 Benatar SR. Detention without trial, hunger strikes and medical ethics. Law Med Health Care 1990;18:140-5. 